\title{
Aeolian sands and soils of a Wetland Biosphere Reserve: The Tablas de Daimiel
}

\author{
Arenas eólicas y sus suelos del humedal Reserva de la Biosfera: las Tablas de Daimiel \\ Areias eólicas e solos de uma Reserva de Zonas Húmidas da Biosfera: As Tablas de \\ Daimiel
}

\section{AUTHORS \\ García-Giménez \\ R. ${ }^{1}$ \\ González-Cascón \\ R. ${ }^{2}$}

\section{Vigil R. ${ }^{1}$}

\section{Jiménez Ballesta}

R. ${ }^{\circledR, 1}$

raimundo.jiménez@ uam.es

@ Corresponding Author

${ }^{1}$ Departament of Geology and

Geochemistry.

Universidad Autónoma de Madrid. Ciudad

Universitaria de

Cantoblanco. 28049

Madrid, Spain.

${ }^{2}$ Department of

Environment.

Instituto Nacional

de Investigación y

Tecnología Agraria y

Alimentaria (INIA).

Crta. de la Coruña,

km. 7,5. 28040 Madrid,

Spain.
Received: 29.05.2015 | Revised: 24.08.2015 | Accepted: 27.08.2015

\section{ABSTRACT}

Three soil profiles were characterized from a sandy area situated in a transitional zone in the "Tablas de Daimiel" UNESCO wetland biosphere reserve (TDNP) in the Mancha Plain (Central Spain). The original thickness of the soil layer in this area was as much as $100 \mathrm{~cm}$, but the combined effect of unbalanced cultivation (including irrigation) and an increasingly dry climate has partially eroded their natural properties, almost leading to a desertification process. The main properties of these soils, classified as Xeropsamments (Soil Survey Staff 2006) or Arenosols (IUSS Working Group WRB 2006), are the dominance of sand in the soil matrix, its basic character, and low soil organic matter and carbonate contents. Scanning electron microscopy of the quartz grain surfaces indicated that the superficial textures were commonly well preserved and characteristic of specific conditions of aeolian formation. Exoscopy revealed a mixture of sub-angular and rounded quartz morphotypes with wellpreserved mechanical impacts on the grain surfaces. These percussion effects are characteristic of aeolian processes and confirmed that mechanical actions were more significant than chemical processes in their pedogenesis. This micromorphological study of the textural sands in the transitional zone of the TDNP revealed that the (red) sands were transported to this area by wind, probably from material of degraded red soils, and deposited on soil horizons previously developed over marls and limestones. The relict character of these materials and specially their susceptibility to degradation should be considered as a priority argument to preserve this area and introduce management measurements to avoid soil erosion.

\section{RESUMEN}

En este estudio se han caracterizado tres perfiles de suelos tomados en una zon a de arenales en las "Tablas de Daimiel", un humedal considerado reserva de la biosfera de la UNESCO (Parque Nacional de las Tablas de Daimiel) y situado en la Llanura Manchega (Centro de España). El espesor original de los suelos en esta zona supera a veces los $100 \mathrm{~cm}$, aunque el efecto combinado del cultivo (incluyendo el regadio) y una climatología cada vez más seca, han degradado parcialmente sus propiedades naturales y han erosionado los suelos, llevando en última instancia a un proceso cercano a la desertificación. Las principales propiedades de estos suelos, clasificados fundamentalmente como Xeropsamments (Soil Survey Staff 2006) o Arenosoles (IUSS Working Group WRB 2006) son, el predominio de arena en la matriz del suelo, su carácter básico y bajo contenido de materia orgánica y carbonatos. El análisis por Microscopía Electrónica de Barrido de la superficie de los granos de cuarzo indica que las texturas superficiales de los mismos están comúnmente bien conservadas y son características de unas condiciones de formación por procesos eólicos. Por otra parte el análisis exoscópico revela una mezcla de morfotipos de cuarzo subangulares y redondeados, con impactos mecánicos bien conservados en la superficie de los granos. Estos efectos de percusión son característicos de procesos eólicos y confirman que, en su edafogénesis, las acciones mecánicas fueron más importantes que los procesos 
químicos. El estudio micromorfológico de las arenas en la zona de transición del PNTD revela que las arenas (rojas) fueron transportadas a esta zona por el viento, probablemente a partir de suelos rojos degradados, y depositadas sobre los suelos previamente desarrollados sobre margas y calizas. El carácter relicto de estos materiales y especialmente su susceptibilidad a la erosión debe considerarse como un argumento para establecer la prioridad de esta área para su protección e implementar las medidas de gestión necesarias para evitar su degradación.

\section{RESUMO}

Neste estudo foram caraterizados três perfis de solo, colbidos numa área de areia da "Tablas de Daimiel" numa reserva de zonas húmidas da Biosfera da UNESCO (TDNP), localizada nas planícies de Llanura Manchega (centro de Espanha). A espessura original das camadas de solo nesta área supera por vezes os $100 \mathrm{~cm}$, mas o efeito combinado de um cultivo dequilibrado (incluindo a rega) e um clima cada vez mais seco têm degradado parcialmente as suas propriedades naturais, levando a um processo de desertificação. As principais propriedades desses solos classificados como Xeropsamments (Soil Survey Staff 2006) ou Arenosols (IUSS Working Group WRB 2006) caraterizamse pelo predominio de areia na matriz do solo, pelo seu caráter básico, e pelo baixo teor em matéria orgânica e carbonatos. A análise por microscopia electrónica de varrimento da superfície dos grãos de quartzo indicaram que as texturas de superfície foram regra geral bem preservadas, sendo características das condiçôes especificas de formação eólica. Além disso, a análise exoscópica revelou uma mistura de tipos morfológicos sub-angular, arredondadas, com impactos mecânicos bem conservados nas superfícies dos grãos de quartzo. Estes efeitos são característicos dos processos de percussão eólica e confirmam que as acções mecânicas foram mais importantes que os processos químicos na sua pedogénese. Este estudo micromorfológico da textura de areias na zona de transição do TDNP revelou que as areias vermelhas foram transportadas para esta zona pelo vento, provavelmente a partir de solos degradados vermelhos, e depositadas sobre os horizontes do solo previamente desenvolvidos sobre margas e calcários. A natureza desses materiais e, especialmente, a sua suscetibilidade à erosão deve ser considerada como um argumento prioritário para a preservação desta zona introduzindo as medidas de gestão necessárias para evitar a sua degradação.

\section{Introduction}

Wetlands, in a number of forms, represent transitional zones between water and land that are found in many regions of the world. The value of these areas has been increasingly recognized in recent years, but the remaining acreage continues to disappear. They are important reservoirs of organic carbon in the global carbon cycle (Mitra et al. 2005; Rodríguez Murillo et al. 2011) and act as efficient filters in hydrological systems (Sánchez Carrillo et al. 2001; Álvarez-Cobelas et al. 2001).

Natural bio-systems such as the Tablas de Daimiel are rarely found in the Iberian Peninsula and in other parts of the world (Sánchez-Carrillo and Angeler 2010). The Tablas de Daimiel constitutes one of the two most important wetlands in the 'Mancha Húmeda'. It is a natural bio-reserve that was declared a National Park in 1973 (National Park of the Tablas de Daimiel TDNP), has been recognized as a Biosphere Reserve since 1981 by the United Nations Educational, Scientific and Cultural Organization (UNESCO) as part of the UNESCO Man and the Biosphere Programme; and was included in the Ramsar Covention in 1982, http:// ramsar.wetlands.org Ramsar Sites Information Service. It was finally designated a Special Bird Protection Zone in 1988 (under European Directive 79/409/EEC, currently amended by Directive 2009/147/EC). 
Despite the importance of this ecosystem, hardly any studies have been completed on the characterization of its soils (Jiménez Ballesta 2010, 2014; Rodriguez Murillo et al. 2011; Aguilera et al. 2011), or the micromorphological features of the soils developed on these aeolian deposits.

Into the park, there is an extension occupied by a singular and unique formation of mainly red sands. Over this sand formation developed in the northeast area of the TDNP, are soils highly susceptible to erosion that have been cited by several authors (Pérez-González and Piles 1985) but never characterized intensively. Hence, the importance of gathering further information for the conservation of this natural park, through more in-depth research on the characteristics of these materials and soils.

There are a several regions in the Iberian Peninsula with favorable conditions for dune development (Bateman and Díez 1999; Bernat and Pérez González 2005a; Bernat et al. 2011). Thus, deposits southeast of the Duero river basin together with those associated with the Guadiana river form the most recent and the most important Quaternary aeolian systems in the Iberian Peninsula (Borja and PérezGonzález 2001).

The cartography of these wind deposits within the Spanish Central region has been published in the Mapa Geológico Nacional (Pérez-González and Piles 1985; Pérez-González and Cabra 1985; Portero and Ramírez 1985). Rodríguez García (1998) completed a geomorphological map of the TDNP and its surroundings, which extended the scope of these deposits.

In addition, scanning electron microscopy (SEM) has been widely applied to the microtextural characterization of aeolian grains (Lisá 2004; Moral-Cardona et al. 1996; Wasel 2012; Costa et al. 2013; Vos et al. 2014). In Spain, Torcal and Tello (1992) used quartz grain exoscopy in fine soil fractions to show its utility in relation to wind transport. Together with instrumental neutron activation analysis, exoscopy has been used by Trinidade et al. (2013) to demonstrate the evidence of post-depositional weathering in quartz grains of coastal dunes. In contrast, Martín et al. (1992) and Moral-Cardona et al. (1996) applied exoscopy for the comparison of soil textures.

The morphology and the appearance of quartz grains reveal the history of their movement and sedimentation. According to Vos et al. (2014), quartz grain surface textures depend on the processes of erosion, transport and deposition to which they were subjected. However, many features of aeolian sand grains are not unique to aeolian origin. The mobility of the sand depends fundamentally on wind intensity, grain size (texture), soil moisture conditions, and the amount of vegetative cover (Kok et al. 2012). The aeolian processes occur when the wind erodes, picks up and transports the particles from the edaphic formations, depositing them at new locations. This may occur because of deflation (removal and carrying away of particles) and/or abrasion when the particles transported by the wind impact on the materials that they find in their way. Three important arid stages have been identified in the southern sub-meseta of Spain during the upper Pleistocene and the Holocene (Rendell et al. 1994; Ruiz-Zapata et al. 2000). These crises of poor humidity were linked to phases characterized by a "strong (continental) seasonality" that depleted the vegetative cover and caused to a large extent, the existence of aeolian type processes.

Wind erosion is a serious problem in many parts of the world, especially in arid and semiarid regions as it physically removes the most fertile soil horizon (Ravi et al. 2010; Ries et al. 2014). In the TDNP these processes created sandy materials upon which certain types of ecologically vulnerable soils have developed. They are susceptible to desertification. In the upper Pleistocene and the Holocene, the flat topography and the scarce vegetative cover favored the wind action causing the formation of aeolian sand deposits, originating from degraded paleosoils. The aim of this paper is to determine the origin of these starting materials as well as to characterize the soils developed on them. 


\section{Material and Methods}

\subsection{Regional setting}

The Tablas de Daimiel (X 438061.1 - Y 4332094.8) is a natural wetland located in Central Spain that represents an exceptional aquatic/ humid environment. It is an example of a characteristically humid ecosystem, (alluvial plains, also known as river tables in this case) in the Mancha Plain (Figure 1). Created around the confluence of the Guadiana river and the
Cigüela river by semi-endorheic drainage and shallow slopes, giving rise (within a semi-arid area) to a singular aquatic and sub-aquatic area of great ecological wealth. At present, this wetland floodplain occupies an area of 1675 ha (Álvarez-Cobelas et al. 2007) that has been significantly reduced in size, as in the recent past it extended to over 15000 ha (Sánchez Carrillo 2000; Álvarez-Cobelas et al. 2001).

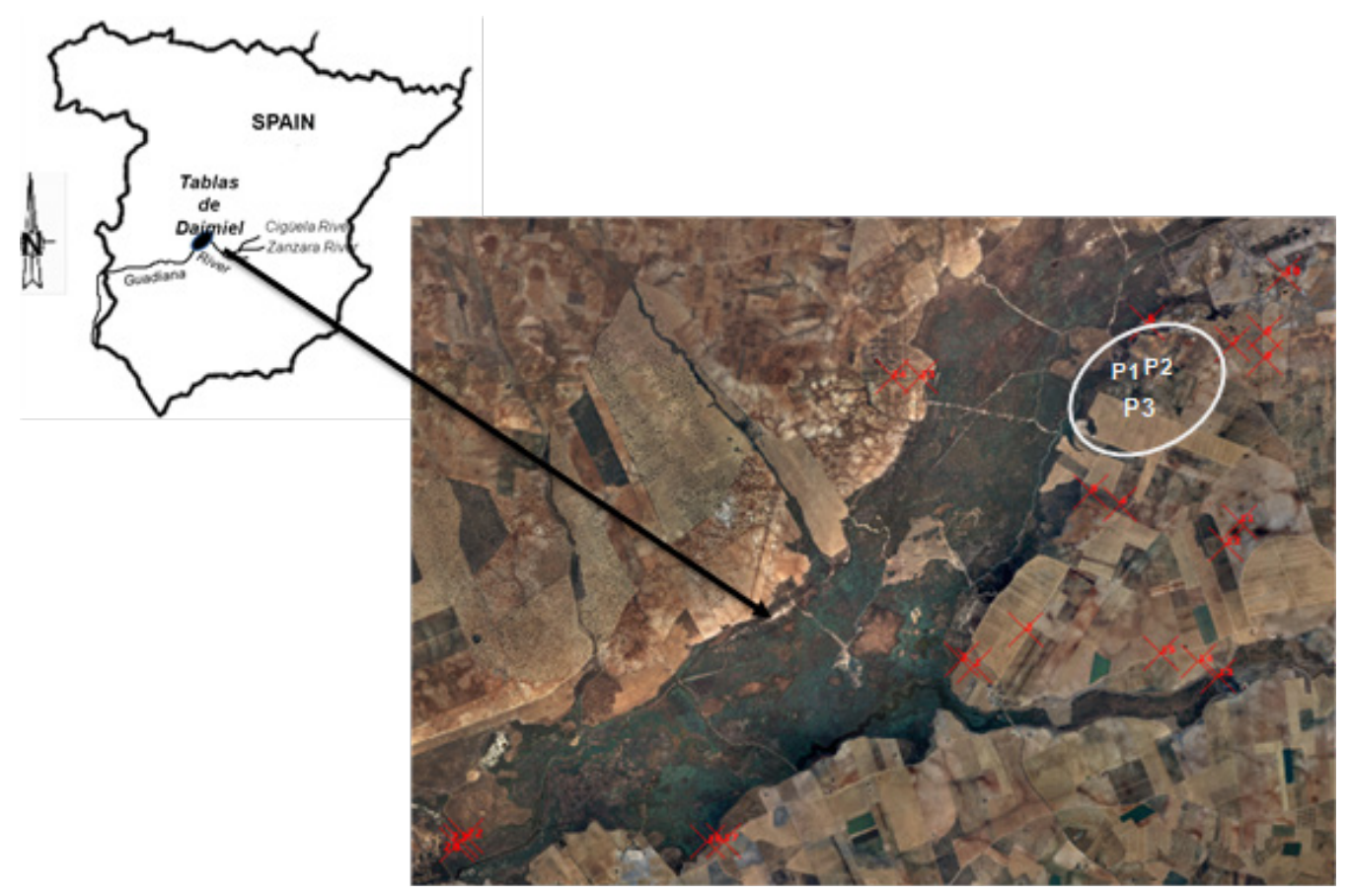

Figure I. Location map of the study area Las Tablas de Daimiel and location of soil sampling sites (P1, P2 and P3) inside the special protection zone.

This lowland river plain has a maximum height above sea level of $620 \mathrm{~m}$ and a minimum of $610 \mathrm{~m}$. It is part of the upper Guadiana river basin, covered by Miocene and Pliocene materials: limes and marls, as well as sands (Portero and Ramirez 1985). The sand fields are a unique sub-environment in an area of approximately $3 \mathrm{~km}^{2}$ on the northeast of the park (Figure 1). The aeolian sands in Central Spain deposited over calcareous material, following geomorphological criteria are very recent, (upper Holocene, at around 3,500 or 3,100 years B.P. as reported Rendell et al. 1994).

The dunes and the aeolian mantle found in the northeast protection zone of the TDNP are part of a landscape of aeolian mantles and dunes that extend from the TDNP to other zones of the Mancha Plain with a maximum length of 145 $\mathrm{km}$ and a width of $8 \mathrm{~km}$ (Portero and Ramírez 
1985; Rodríguez and Pérez-González 2002; Bernat et al. 2011). The surficial topography of extensive dunes has practically disappeared due to the anthropic action of land ploughing (Bernat et al. 2011). At present, they are sandy paleodunes relatively close to the northeast of the TDNP that were formed under the action of an extremely dry climate (Bernat et al. 2011). The crumbly properties of the sandy soils and its agricultural overexploitation have degraded these deposits.

The area is characterized by a semi-arid climate with an annual evapotranspiration of around $750-800 \mathrm{~mm}$ and an average annual precipitation of $370.6 \mathrm{~mm}$ and average annual temperature of $14.4{ }^{\circ} \mathrm{C}$ (Ciudad Real Station). The region has a continental climate as in the rest of the Mancha Plain, with cold winters (lows close to $-10^{\circ} \mathrm{C}$ ), followed by very hot and extremely dry summers with maximum highs that can rise above $40{ }^{\circ} \mathrm{C}$. The area has a xeric soil moisture regime, and a mesic temperature regime according to Soil Survey Staff (2006). The topography in this area is relatively flat. The vegetative cover of the originally sandy grasslands is practically destroyed, as the soils have been used for agricultural purposes and historically overgrazed, with only a few holm oak trees (Quercus ilex) remaining (Cirujano et al. 1996). Therefore the actual vegetation in the study area differs completely from the main vegetation communities present in the TDNP that includes cut-sedge vegetation and wooded areas as well as waterfowl populations (ÁlvarezCobelas et al. 2001).

Based on geological cartography and aerial photography of the TDNP, a previous soil survey was carried out in 24 sites representatives of special protection zone of the park (Jiménez Ballesta 2014) around the flooding area (Figure 1). There is a notable diversity of soil types in the NPTD. The most abundant found were Fluvisols, Calcisols, Regosols, Leptosols, Cambisols, Histosols and Luvisols (IUSS Working Group WRB 2006) (Jiménez Ballesta 2010, 2014). However, in the Aeolian mantles and dunes study area, mainly Arenosols and
Calcisols can be found. These soils showed massive structures and characteristic uniform red colors.

\subsection{Sampling procedure}

Soil profiles from three geo-referenced locations were described according to FAO (2006) and soil samples at all the horizons in each profile were taken (Table 1). Profiles 1 and 2 are the characteristic sand soils from the study area while profile 3 is representative of the contact zone between the paleosand layers and the marls. The profile 2 is the most representative of the sand area (its morphology is reduced to an Ap horizon lying over the sand stratum). Therefore, the microtextural analysis were performed in the underlying $\mathrm{C}$ horizon. The profile 1 showed the influence by the carbonate presence in the profile basis. The profile 3 represents the transition zone, as the original carbonate materials (marls) together with the superficial sand layer have determined its formation process.

The profiles 1, 2 are Arenosols and showed a morphology of type Ap, C1 and C2k and Ap, C1 and C2 (Table 1) while the profile 3 is a Calcisol with $\mathrm{Ap}, \mathrm{A} / 2 \mathrm{Ckm}$ and $2 \mathrm{Ckm}$ morphology. All soils had an acceptable drainage. The surface horizon $A p$ is the consequence of agricultural exploitation. No buried horizons from paleosoils under the sand mantle were found in the profiles studied. No cryoturbation was detected, and the calcium carbonate content in the soils effervesced with hydrochloric acid in all the studied profiles. 
Table 1. General description and macromorphological characteristics of researched soils

a. Profile 1

\begin{tabular}{|c|c|c|c|c|c|c|c|c|}
\hline $\begin{array}{l}\text { Soil Type WRB/ } \\
\text { Soil Taxonomy }\end{array}$ & $\begin{array}{l}\text { Location } \\
\text { Coordinates }\end{array}$ & Altitude (m) & $\begin{array}{l}\text { Parent } \\
\text { Material }\end{array}$ & Vegetation & Topography & Slope & Drainage & Stoniness \\
\hline $\begin{array}{c}\text { Haplic Arenosol } \\
\text { (Calcaric, Novic)/ } \\
\text { Typic Xeropsamment }\end{array}$ & $\begin{array}{c}X \\
442928,483 \\
Y \\
335615,084\end{array}$ & 610 & Sands & $\begin{array}{l}\text { Wasteland } \\
\text { with some } \\
\text { oak }\end{array}$ & Plain & C-1 Flat & $\begin{array}{c}\text { C-5 } \\
\text { Somewhat } \\
\text { excessively } \\
\text { drained }\end{array}$ & $\begin{array}{l}\text { C-0 } \\
\text { Non- } \\
\text { stony }\end{array}$ \\
\hline $\begin{array}{l}\text { Horizon Depth } \\
\qquad(\mathrm{cm})\end{array}$ & $\begin{array}{l}\text { Colour } \\
\text { (dry) }\end{array}$ & Structure & Consistence & Roots & Pores & Boundary & $\begin{array}{c}\text { Stoniness } \\
(\%)\end{array}$ & \\
\hline$A_{p}(0-21)$ & $\begin{array}{l}\text { 7.5YR 5/4 } \\
\text { Brown }\end{array}$ & $\begin{array}{l}\text { Single grain } \\
\text { to weak } \\
\text { granular } \\
\text { fine }\end{array}$ & $\begin{array}{l}\text { Non sticky, } \\
\text { non plastic, } \\
\text { loose and } \\
\text { soft }\end{array}$ & Few fines & $\begin{array}{l}\text { Many, } \\
\text { all sizes }\end{array}$ & $\begin{array}{l}\text { Gradual } \\
\text { and wavy }\end{array}$ & 2 & \\
\hline C1 (21-68) & $\begin{array}{l}\text { 5YR 5/8 } \\
\text { Yellowish } \\
\text { red }\end{array}$ & $\begin{array}{l}\text { Massive to } \\
\text { single grain }\end{array}$ & $\begin{array}{l}\text { Non sticky, } \\
\text { non plastic, } \\
\text { loose and } \\
\text { soft }\end{array}$ & Without & $\begin{array}{l}\text { Common, } \\
\text { all sizes }\end{array}$ & $\begin{array}{l}\text { Gradual } \\
\text { and wavy }\end{array}$ & 0 & \\
\hline$C 2_{k}(>68)$ & $\begin{array}{l}\text { 5YR 6/6 } \\
\text { Reddish } \\
\text { yelow }\end{array}$ & $\begin{array}{l}\text { Moderate } \\
\text { to weak } \\
\text { granular } \\
\quad \text { fine }\end{array}$ & $\begin{array}{l}\text { Non sticky, } \\
\text { non plastic, } \\
\text { loose and } \\
\text { soft }\end{array}$ & Without & $\begin{array}{l}\text { Common, } \\
\text { all sizes }\end{array}$ & $\begin{array}{l}\text { Diffuse } \\
\text { and wavy }\end{array}$ & 0 & \\
\hline
\end{tabular}

a. Profile 2

\begin{tabular}{|c|c|c|c|c|c|c|c|c|}
\hline $\begin{array}{l}\text { Soil Type WRB/ } \\
\text { Soil Taxonomy }\end{array}$ & $\begin{array}{l}\text { Location } \\
\text { Coordinates }\end{array}$ & Altitude (m) & $\begin{array}{l}\text { Parent } \\
\text { Material }\end{array}$ & Vegetation & Topography & Slope & Drainage & Stoniness \\
\hline $\begin{array}{c}\text { Haplic Arenosol } \\
\text { (Calcaric, Novic)/ } \\
\text { Typic Xeropsamment }\end{array}$ & $\begin{array}{c}X \\
443287,596 \\
Y \\
4335736,768\end{array}$ & 611 & Sands & $\begin{array}{c}\text { Olives } \\
\& \text { some } \\
\text { vineyards }\end{array}$ & Plain & C-1 Flat & $\begin{array}{c}\text { C-5 } \\
\text { Somewhat } \\
\text { excessively } \\
\text { drained }\end{array}$ & $\begin{array}{l}\text { C-0 } \\
\text { Non- } \\
\text { stony }\end{array}$ \\
\hline $\begin{array}{l}\text { Horizon Depth } \\
\qquad(\mathrm{cm})\end{array}$ & $\begin{array}{l}\text { Colour } \\
\text { (dry) }\end{array}$ & Structure & Consistence & Roots & Pores & Boundary & $\begin{array}{c}\text { Stoniness } \\
(\%)\end{array}$ & \\
\hline$A_{p}(0-26)$ & $\begin{array}{l}\text { 7.5YR 5/4 } \\
\text { Brown }\end{array}$ & $\begin{array}{l}\text { Single grain } \\
\text { to weak } \\
\text { granular } \\
\text { fine }\end{array}$ & $\begin{array}{l}\text { Non sticky, } \\
\text { non plastic, } \\
\text { loose and } \\
\text { soft }\end{array}$ & Few fines & $\begin{array}{l}\text { Many, } \\
\text { all sizes }\end{array}$ & $\begin{array}{l}\text { Abrupt } \\
\text { and } \\
\text { smooth }\end{array}$ & 2 & \\
\hline C1 (26-70) & $\begin{array}{c}\text { 7.5YR 5/6 } \\
\text { Strong brown }\end{array}$ & $\begin{array}{l}\text { Massive to } \\
\text { single grain }\end{array}$ & $\begin{array}{l}\text { Non sticky, } \\
\text { non plastic, } \\
\text { loose and } \\
\text { soft }\end{array}$ & Without & $\begin{array}{l}\text { Many, } \\
\text { all sizes }\end{array}$ & $\begin{array}{l}\text { Diffuse } \\
\text { and flat }\end{array}$ & 0 & \\
\hline C2 (> 70) & $\begin{array}{c}\text { 7.5YR 5/8 } \\
\text { Strong brown }\end{array}$ & $\begin{array}{l}\text { Massive to } \\
\text { single grain }\end{array}$ & $\begin{array}{l}\text { Non sticky, } \\
\text { non plastic, } \\
\text { loose and } \\
\text { soft }\end{array}$ & Without & $\begin{array}{l}\text { Common, } \\
\text { all sizes }\end{array}$ & $\begin{array}{l}\text { Diffuse } \\
\text { and wavy }\end{array}$ & 0 & \\
\hline
\end{tabular}


b. Profile 3

\begin{tabular}{|c|c|c|c|c|c|c|c|c|}
\hline $\begin{array}{l}\text { Soil Type WRB/ } \\
\text { Soil Taxonomy }\end{array}$ & $\begin{array}{l}\text { Location } \\
\text { Coordinates }\end{array}$ & Altitude $(\mathrm{m})$ & $\begin{array}{l}\text { Parent } \\
\text { Material }\end{array}$ & Vegetation & Topography & Slope & Drainage & Stoniness \\
\hline $\begin{array}{c}\text { Epipetric Calcisol } \\
\text { (Skeletic, Novic)/ } \\
\text { Petrocalcic } \\
\text { Calcixerept }\end{array}$ & $\begin{array}{c}X \\
443285,502 \\
Y \\
335455,261\end{array}$ & 617 & $\begin{array}{l}\text { Sands and } \\
\text { marls }\end{array}$ & Olives & Wavy & $\begin{array}{c}\text { C-2 } \\
\text { Gently } \\
\text { sloping }\end{array}$ & $\begin{array}{c}\text { C-4 } \\
\text { Well } \\
\text { drained }\end{array}$ & $\begin{array}{c}\text { C-1 } \\
\text { Slightly } \\
\text { stoney }\end{array}$ \\
\hline $\begin{array}{l}\text { Horizon Depth } \\
\quad(\mathrm{cm})\end{array}$ & $\begin{array}{l}\text { Colour } \\
\text { (dry) }\end{array}$ & Structure & Consistence & Roots & Pores & Boundary & $\begin{array}{c}\text { Stoniness } \\
(\%)\end{array}$ & \\
\hline$A_{p}(0-18)$ & $\begin{array}{c}\text { 7.5YR 5/4 } \\
\text { Brown }\end{array}$ & $\begin{array}{c}\text { Weak } \\
\text { granular to } \\
\text { single grain }\end{array}$ & $\begin{array}{l}\text { Non sticky, } \\
\text { non plastic, } \\
\text { loose and } \\
\text { soft }\end{array}$ & $\begin{array}{l}\text { Common } \\
\text { medium } \\
\text { and fine }\end{array}$ & $\begin{array}{l}\text { Many, very } \\
\text { coarse }\end{array}$ & $\begin{array}{l}\text { Gradual } \\
\text { and wavy }\end{array}$ & 15 & \\
\hline $\mathrm{A} / 2 \mathrm{C}_{\mathrm{km}}(18-42)$ & $\begin{array}{l}7.5 \text { YR 4/2 } \\
\text { Dark brown }\end{array}$ & $\begin{array}{l}\text { Moderate } \\
\text { blocky } \\
\text { subangular } \\
\text { médium }\end{array}$ & $\begin{array}{l}\text { Non sticky, } \\
\text { non plastic, } \\
\text { firm and soft }\end{array}$ & Many fine & $\begin{array}{l}\text { Common } \\
\text { medium } \\
\text { and coarse }\end{array}$ & $\begin{array}{l}\text { Abrupt } \\
\text { and } \\
\text { smooth }\end{array}$ & 10 & \\
\hline $2 C_{\mathrm{km}}(42-84)$ & $\begin{array}{c}\text { 7.5YR } 7 / 2 \\
\text { Pinkish grey }\end{array}$ & Massive & $\begin{array}{l}\text { Very sticky, } \\
\text { non plastic } \\
\text { and } \\
\text { very hard }\end{array}$ & Without & Without & $\begin{array}{l}\text { Diffuse } \\
\text { and wavy }\end{array}$ & 50 & \\
\hline
\end{tabular}

\subsection{Analytical methods}

The soil samples were air dried and sieved $(<2 \mathrm{~mm})$. Soil texture was determined by the hydrometer method (Gee and Bauder 1986) in three replicates. Textural curves were obtained with a laser beam diffraction spectrometer (Sympatec Helos KA), equipped with a wet feed system, using isopropyl alcohol as a nonreactive dispersant; the samples underwent agitation and zonification processes to ensure acceptable particle dispersion. Soil $\mathrm{pH}\left(\mathrm{H}_{2} \mathrm{O}\right)$ was potentiometrically measured in a 1:2.5 soil/ water ratio and electrical conductivity in a 1:5 soil/ water suspension (International Organization for Standardization 1994). Calcium carbonate was analyzed by the volumetric calcimeter method (International Organization for Standardization 1995). The soil organic matter was quantified by the Walkley and Black wet oxidation method (Nelson and Sommers 1982). The sieved fraction of 60 to $125 \mu \mathrm{m}$ was used for the sand mineralogy study. The grain identification for this purpose was conducted in an Orto Plan Pol Zeiss petrographic microscopy, separating the heavy and light fractions with bromoform. The mineralogical analysis of the clay and the fine fraction was performed by X-Ray Diffraction (XRD), using the random powder method for the bulk sample and the oriented slides method (Moor and Reynolds 1989). Semiquantitative mineralogical analysis was based on the diffraction peaks (Kisch 1990).

Exoscopic observations were performed on quartz grains larger than $0.25 \mathrm{~mm}$ separated from other sizes. Images of surface textures of 5 quartz grains were acquired. Selected typical textures of each studied quartz grain were investigated to obtain several photomicrographs. Morphological characterization was conducted following the concepts of previous studies (Helland and Holmes 1997; Wasel 2012; Vos et al. 2014). Systematic observations were completed using an SEM-EDX device (PHILIPS XL30, W source, DX4i analyzer and Si/Li detector). 10 grain per sample were systematically analyzed using an SEM-EDX device (PHILIPS XL30, W source, DX4i analyzer and Si/Li detector). 


\section{Results}

The physicochemical soil characterization confirmed the soil type description (Table 2). In the profiles 1 and 2 the sand fraction dominated the soil mineral matrix. The soils have low carbonate contents, with a basic character, very low organic carbon contents and low electrical conductivities. The soil carbon contents contrast with the soils inside the TDNP wetland where Rodríguez Murillo et al. (2011) found an average value of $10 \%$ in the $20-30 \mathrm{~cm}$ layer. The presence of carbonates is common in a large number of soils in the surrounding areas (Aguilera et al. 2011; Jiménez Ballesta 2014). Profile 3 however, being developed over a sand-marl layer, has a more balanced clay loam texture with higher carbonate contents in depth and $1 \%$ higher organic carbon content in the superficial Ap horizon. The sandy character and scarcity of organic material justifies the weak soil structure.
Figure 2 shows the textural curves for representative samples of the three profiles in which the sand fraction dominates. The granulometric curves of profiles 1 and 2 are typical of Aeolian samples, with a grain size monomodal right skewed distribution curve. They can generally be classified as well sorted fine to medium grained sand in profile 1 and shifted to medium-coarse grained sand in profile 2. These grain-distribution curves with pronounced kurtosis and well sorted distributions can be interpreted as the product of dust storms generated by low-altitude winds (Sun et al. 2004). The curve of profile 3 presents a bimodal distribution with the high peak in the fine to medium grained sand and a secondary peak centred under $50 \mu \mathrm{m}$ diameter category, revealing the enhanced presence of the fine fraction materials (41\%).

Table 2. Some pedological properties of selected soils: particle size distribution, textural class, pH, electrical conductivity, organic matter and calcium carbonate content of three soil profiles

\begin{tabular}{|c|c|c|c|c|c|c|c|c|c|}
\hline Profile & Horizon & $\begin{array}{c}\text { Sand } \\
\%\end{array}$ & $\begin{array}{l}\text { Silt } \\
\%\end{array}$ & $\begin{array}{c}\text { Clay } \\
\%\end{array}$ & $\begin{array}{c}\text { Textural } \\
\text { classification }\end{array}$ & $\begin{array}{c}\mathrm{pH} \\
\left(\mathrm{H}_{2} \mathrm{O}\right)\end{array}$ & $\begin{array}{c}\text { Electrical } \\
\text { Conductivity } \\
(\mu \mathrm{S} / \mathrm{cm})\end{array}$ & $\begin{array}{c}\text { Organic } \\
\text { matter } \\
(\%)\end{array}$ & $\begin{array}{c}\mathrm{CaCO}_{3} \\
(\%)\end{array}$ \\
\hline \multirow{3}{*}{1} & $A_{p}(0-21 \mathrm{~cm})$ & 86 & 7 & 7 & Sand & 6.7 & 1400 & 0.3 & 8 \\
\hline & C1 $(21-68 \mathrm{~cm})$ & 89 & 5 & 6 & Sand & 7.1 & 970 & 0.1 & 8 \\
\hline & $\mathrm{C} 2_{\mathrm{k}}(>68 \mathrm{~cm})$ & nd & nd & nd & nd & 7.9 & 170 & 0.0 & 15 \\
\hline \multirow{3}{*}{2} & $A_{p}(0-26 \mathrm{~cm})$ & 89 & 5 & 6 & Sand & 7.7 & 140 & 0.5 & 3 \\
\hline & C1 $(26-70 \mathrm{~cm})$ & 77 & 12 & 11 & Clay loam & 8.0 & 250 & 0.1 & 14 \\
\hline & $\mathrm{C} 2(>70 \mathrm{~cm})$ & 90 & 5 & 5 & Sand & 8.0 & 140 & 0.1 & 14 \\
\hline \multirow{3}{*}{3} & $A_{p}(0-18 \mathrm{~cm})$ & 59 & 25 & 16 & Clay loam & 7.5 & 240 & 1.4 & 5 \\
\hline & $\mathrm{A} / 2 \mathrm{C}_{\mathrm{km}}(18-42 \mathrm{~cm})$ & 51 & 30 & 19 & Clay loam & 7.6 & 130 & 0.6 & 12 \\
\hline & $2 \mathrm{C}_{\mathrm{km}}(>42 \mathrm{~cm})$ & nd & nd & nd & nd & 7.7 & 130 & 0.0 & 59 \\
\hline
\end{tabular}

$\left.{ }^{*}\right) \mathrm{nd}=$ not determined. 
The sand fraction of the studied soils presented a light fraction (>90\%) with quartz and feldspar/ calcite; the heavy minerals identified were tourmaline, zircon, garnet, staurolite, rutile, hornblende and anatase (Figure 3). In the Arenosols tourmaline and zircon represented the majority constituting $60 \%$ of the heavy minerals identified. These results are in accordance with the studies of Aleixandre et al. (1977) in the characterization of the dunes in the Mancha Plain.
Regarding the total mineralogy, there were few qualitative differences between horizons and profiles (Table 3). The mineral assemblages are dominated by quartz and phyllosilicates with a variable content of calcite. Quartz is found in all profiles, especially in the surface horizons. The clay fraction is mainly composed of illite and kaolinite. In the deep horizons, the major component is calcite. This result is consistent with the composition of the sand and the calcium carbonate content of the marls.

Table 3. Semiquantitative total sample and clay mineral fraction (\%)

\begin{tabular}{|c|c|c|c|c|}
\hline & Horizon & $\begin{array}{l}\text { Phyllosilicates } \\
\text { Kaolinite/lllite }\end{array}$ & Calcite & Quarzt \\
\hline \multirow{3}{*}{ Profile 1} & $A_{p}$ & $\begin{array}{c}19 \\
10 / 90\end{array}$ & nd & 81 \\
\hline & $\mathrm{C} 1$ & $\begin{array}{c}47 \\
15 / 85\end{array}$ & nd & 53 \\
\hline & $\mathrm{C} 2_{\mathrm{k}}$ & $\begin{array}{c}3 \\
90 / 10\end{array}$ & 51 & 46 \\
\hline \multirow{3}{*}{ Profile 2} & $A_{p}$ & $\begin{array}{c}45 \\
10 / 90\end{array}$ & nd & 55 \\
\hline & $\mathrm{C} 1$ & $\begin{array}{c}5 \\
90 / 10\end{array}$ & 90 & 5 \\
\hline & $\mathrm{C} 2$ & $\begin{array}{c}5 \\
90 / 10\end{array}$ & 90 & 5 \\
\hline \multirow{3}{*}{ Profile 3} & $A_{p}$ & $\begin{array}{c}28 \\
45 / 55\end{array}$ & 46 & 26 \\
\hline & $\mathrm{A} / 2 \mathrm{C}_{\mathrm{km}}$ & $\begin{array}{c}14 \\
12 / 88\end{array}$ & 78 & 8 \\
\hline & $2 \mathrm{C}_{\mathrm{km}}$ & $\begin{array}{c}5 \\
0 / 100\end{array}$ & 95 & 5 \\
\hline
\end{tabular}

$\left(^{*}\right)$ nd $=$ not determined 
Profile 1: Haplic Arenosol (Ap 86\% sand, C1 89\% sand)

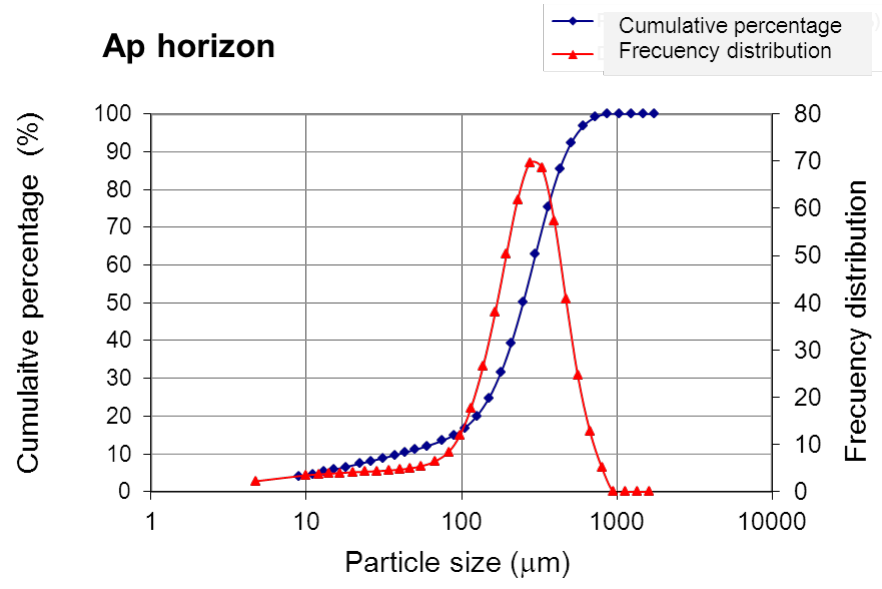

Profile 2: Haplic Arenosol (Ap 89\% sand, C1 77\% sand)

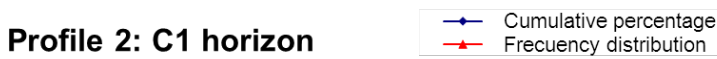

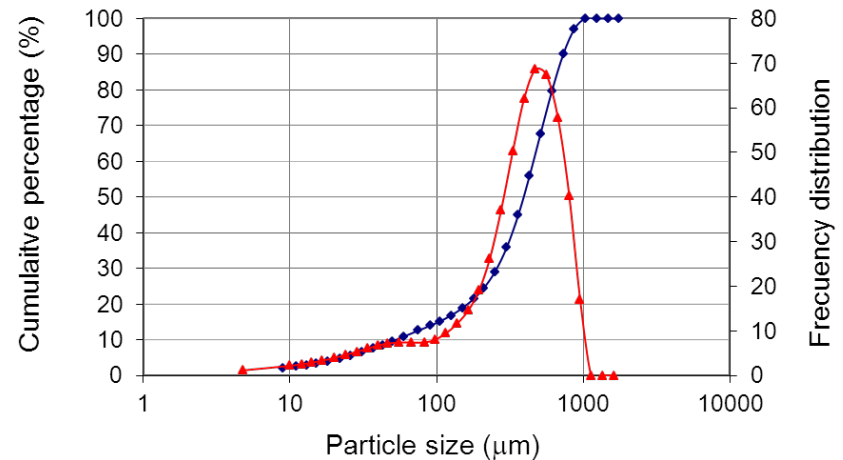

Profile 3: Epipetric Calcisol (Ap 59\% sand, A/2C $\mathrm{km}_{\mathrm{km}} 51 \%$ sand)
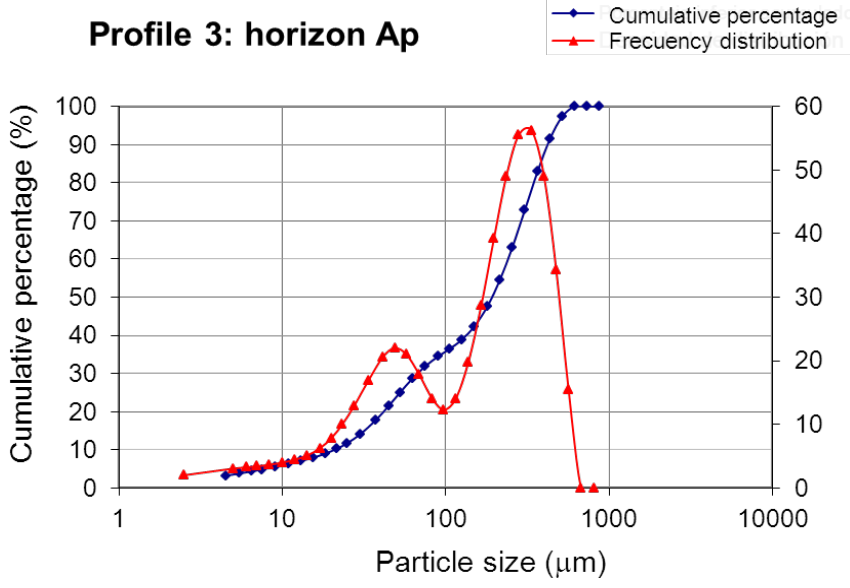

Figure 2. Grain-size frequency distribution curves. 
Profile 1

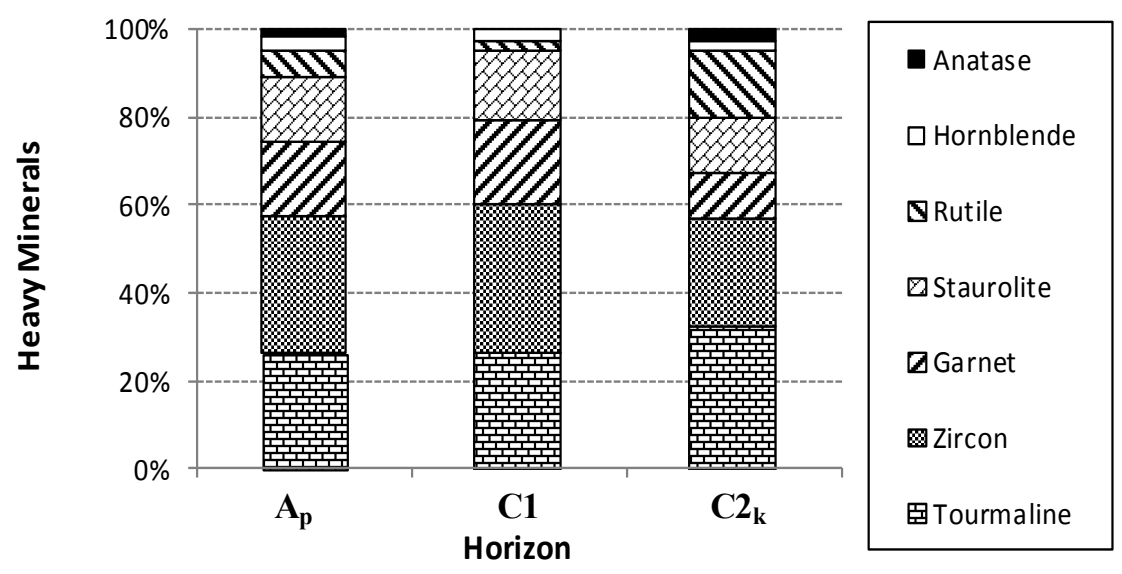

Profile 2

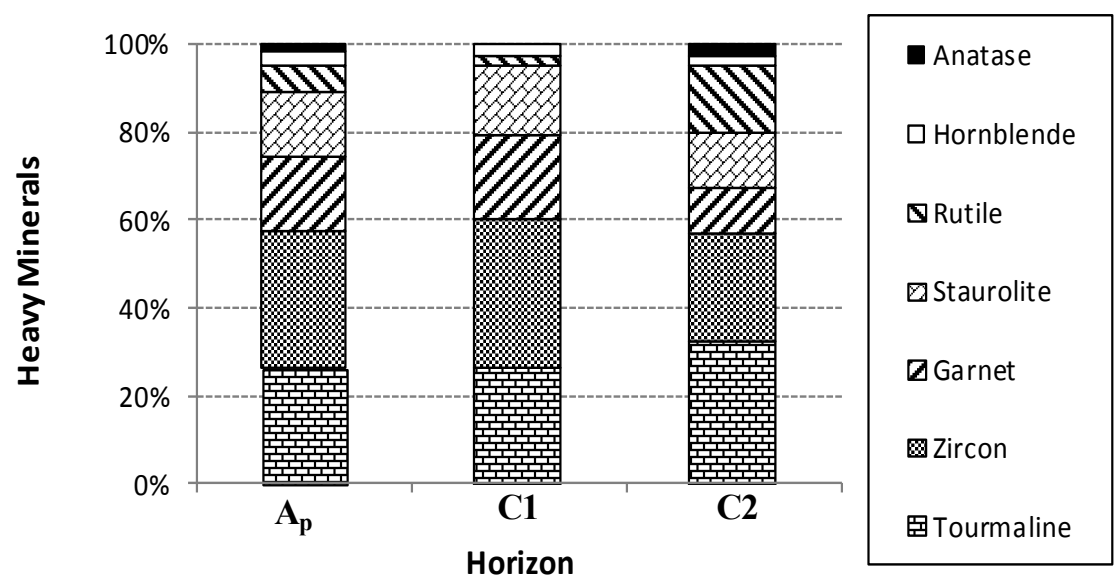

Profile 3

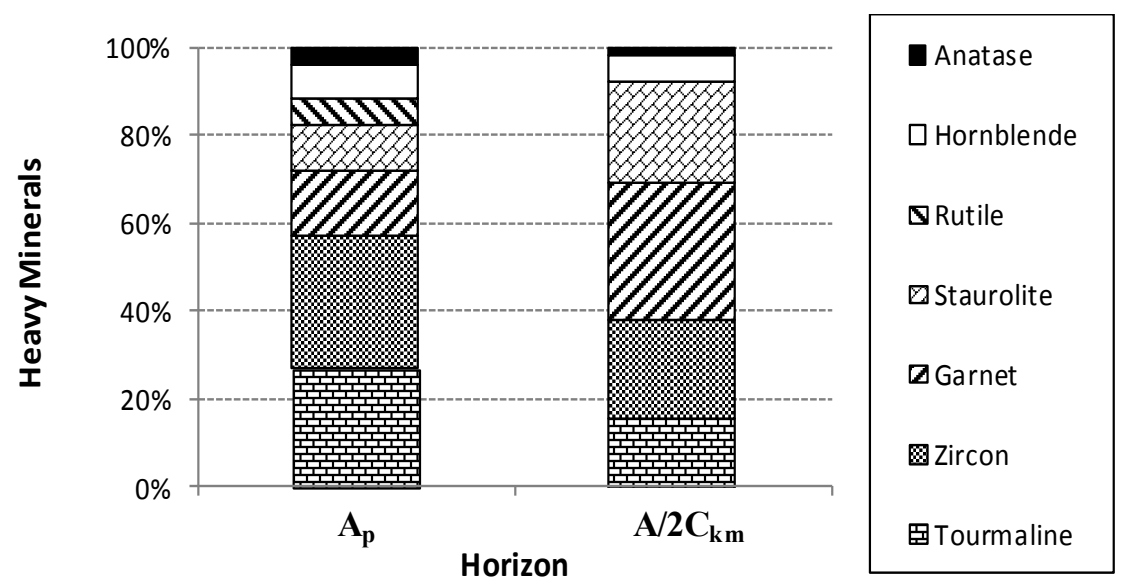

Figure 3. Heavy mineral contents of the different soil profiles. 


\subsection{Surface textural analysis of quartz grains}

The quartz grains under study were milky, showing a subangular nature (with clear and rounded edges, Figures $4 a, 4 b$ and $4 c$ ). Their external appearance was matt, which is associated with transport processes originated from dissolution and abrasion that wears down their surfaces.

Subangular quartz grains occur as fresh, irregular, angular fragments, with no sign of polyhedral faces. Two types of microstructures were observed on quartz grain surfaces: (i) precipitation of silica on the surface of grains in lace-like patterns and (ii) corrosive etched microstructures. They are grains of fractured quartz and slightly rounded in which the fracture zones are easily distinguished (Figure 4b). They have clean surfaces, marked edges and are characterized primarily by mechanical features such as conchoidal breakage patterns, $v$-shaped pits, and straight or curved grooves; secondly, there is chemical action in the form of silica precipitates.

Many impacts may be observed on the surfaces that are typical of aeolian transport because of the impact of the edges of some grains against others during transport (Figure 4d). The existence, in some cases, of surfaces with triangular impacts (Figure 4e) is not consistent with the predominant directions of transport, but with a turbulent regime, possibly linked to small tornadoes and the circular movement of winds. Nevertheless, the surfaces are hidden by the dissolution of base material. In Figure 4f, concentric formations may be recognized on the lower right and left that are identified with the earliest movements in the transport of quartz grains.

On some grains, a corroded or squeezed aspect may be observed, which may be interpreted as an intense surface dissolution process (Figure 4g), which in this case is observed on quartz grains from profile 1. Given the observation of triangular marks shown in Figure 5b, linked to aeolian transport by saltation, it has to be noted that they were earlier than the dissolution phenomena.
Both processes (transport and dissolution) originated in the same direction, which suggests that the winds were always blowing in the same direction; the runoff water had a role in dissolution process, almost certainly running off in the same direction. Analyzing the Figure 4, a certain similarity with the figures in Peter and Tietz (2011) could be found. They consider the presence of chattermark trails as indicators for a depositional stage within a sedimentary cycle in a wet tropical to subtropical climate. In our study, the impact trajectory is much shorter than the chattermark trails, therefore the tropical or subtropical origin was discarded. Although the material originated previous to the aeolian transport could be generated in a tropical climate; the intense red color character could be an indicator of it.

All the above features are especially present in profiles 1 and 2, although also in the surface horizon of profile 3 . In this latter profile, which constitutes the transitional zone of the sands towards the TDNP, the quartz grain faces are better defined and the processes of dissolution and/or transport are less acute than in the earlier samples (Figures $4 \mathrm{~b}$ and $4 \mathrm{c}$ ). The presence of rounded grains suggests (profile 3 ) that significant amounts of quartz grains are of a recycled origin. As an interpretation, the authors were in accordance with the conclusions drawn by Aleixandre et al. (1977), who indicated that sub-rounded grains predominate in continental dunes of the Mancha Plain, which would indicate a limited transport from the source area (Bernat et al. 2011). Most aeolian sand deposits consist of subrounded, moderately-sorted to well-sorted, fine sand (Goudie and Watson 1981; Goudie et al. 1987; Lancaster 1986, 1989).

Moreover, post-settlement deposits were observed that covered the quartz grains, filling in the gaps (Figure 4h). This suggests that quartz grains released from the rock then stagnated in cold water, leaving extensive silica deposits. The amorphous silica film covers multiple cavities in the form of $a v$ that is hidden by the coating. 

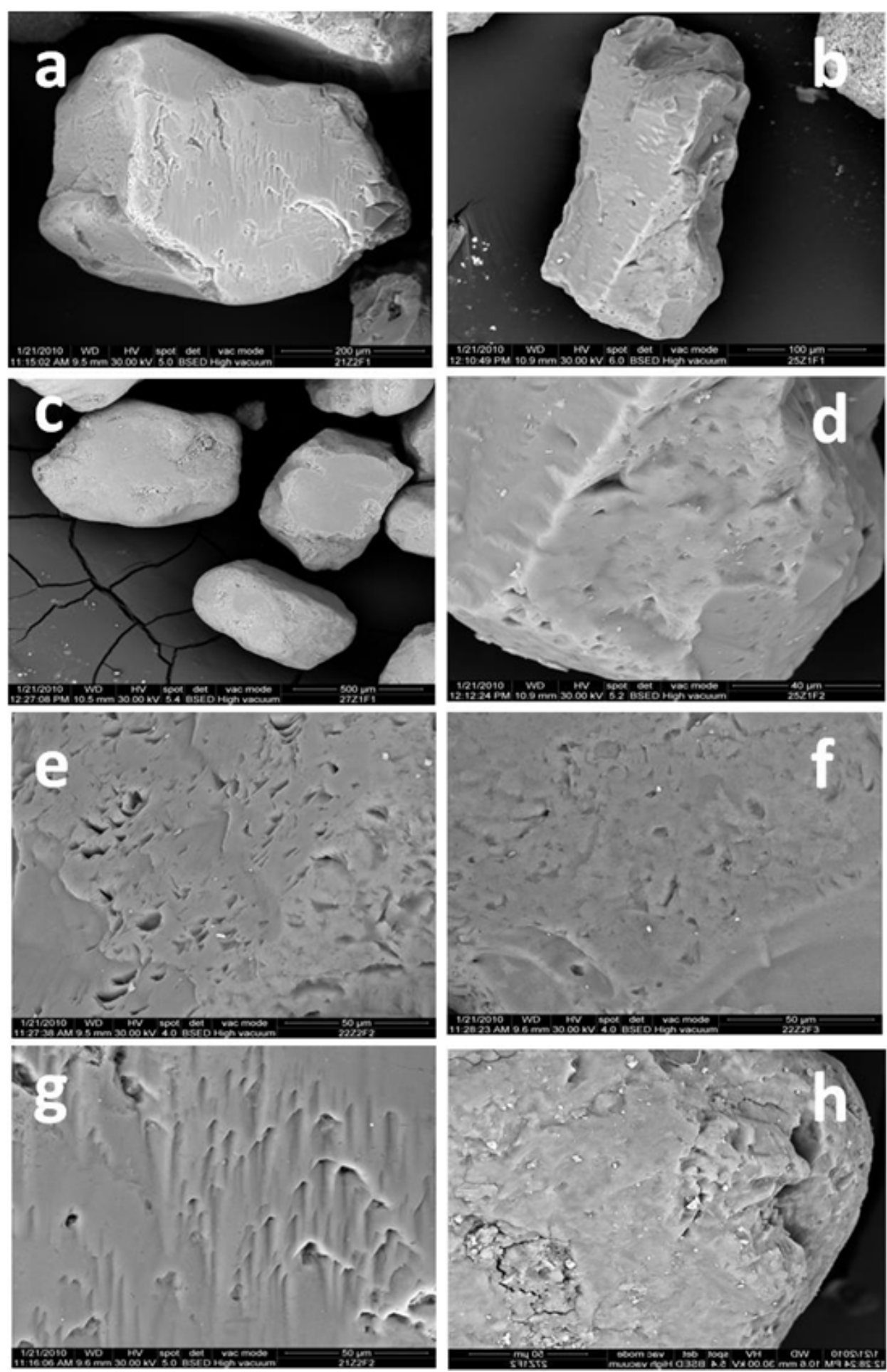

Figure 4. Scanning electron microphotographs of different quartz grains exhibiting: (a) profile 1, subangular nature and corroded or squeezed aspect (corrosive etched microstructures), (b) profile 1, quartz grain with easily distinguished fracture zones, (c) profile 3 , external appearance was matt, (d) profile 1, impacts on the surfaces (typical of aeolian transport), (e) profile 2, surfaces with triangular impacts, (f) profile 2, concentric formations (earliest movements in the transport of quartz grains), (g) profile 1, dissolution phenomena, (h) profile 3, subrounded quartz grain; post-settlement deposits that covered the quartz grains, filling in the gaps. 


\section{Discussion}

The analysis of the quartz grains suggest that the grains have undergone an aeolian process. Since the grain distribution curves analysis have the high peaks in the fine to medium sand sizes, most of the soil quartz grains in the profiles under study were probably derived from soils or sediments from the surrounding area. By moderate storms, coarse particles were transported by saltation and short-term suspension for a distance of a few hundreds of kilometers, while finer particles $(<20 \mu \mathrm{m})$ mainly transported by long-term suspension are moved over hundreds to thousands kilometers (Muhs et al. 2007; Crouvi et al. 2008). Chattermark trails are a series of linearly arranged, rune-like grooves on surfaces of minerals grains (Peter and Tietz 2011). For these authors, they are formed by blunt collisions in a sediment transport stage before experiencing some dissolution during a depositional stage in a tropical climate. The absence of chattermark trails or similar to chattermark trails indicates a depositional stage within a sedimentary cycle but no necessarily in a wet tropical to subtropical climate; probably they were transported from a nearby local source under more arid conditions by aeolian action. The sand colour and specially the mineralogy of the sand grains point out that the transported sand particles were probably edaphic material from degraded red soils, that are very common in La Mancha Plain (Conde-Bueno et al. 2008).

Rubification is a slow process in arid and semiarid climate (Roskin et al. 2012). The conditions required for the rubification process (wetter moisture regimes, and long pedogentic formation times) indicate that the process cannot take place in situ under the actual climate conditions (Goran 2003; Sierra et al. 2009), confirming the aeolian origin of the sand deposits.

Quaternary comprises a multitude of periods with similar climatic-steppic/desert-conditions, as demonstrated by many studies, such as the study on Quaternary aeolian sands in Central Spain (Duero basin) by Bateman and Diez (1999). Pye and Mazzullo (1994) observed that shape differences could be attributed to postdepositional weathering in a humid tropical climate in two generations of stabilized parabolic dunes from North Queensland, Australia. Most aeolian sands are truly polycyclic and represent the results of numerous cycles, leading to a situation in which specific features are very hard to attribute to a single cycle. The sands in the area of study, given their red colour, are derived from earlier, most likely Pliocene deposits, which are widely distributed in the region. Bernat and Pérez González (2005b) show an extensive description on the occurrence, characteristics and origin of the dunes, showing that these dunes basically date from the Younger Dryas and the late Holocene. Aeolian activity in Western Europe has been related to changing climate conditions (Clemmensen et al. 2001; Bateman and Godby 2004). Therefore, migration of dunes during different pulses of aeolian activity could be happened.

Hence, the specific conclusions of this study are that the red sands would have been transported by wind and deposited on earlier soils developed over marls and limestones layers. The scarce and dispersed vegetation has led to intensify the deposition processes increasing the sand layers depth.

Finally, discussions on conservation and use of this type of semiarid soils should focus on work programs, to address either mitigation or adaptation (or both) that should take into account the vulnerability of the soil subtracts in the surrounding TDNP area, like the soils under study. The relict character of these materials should be considered as a priority argument to preserve this area and introduce management measurements to avoid soil erosion. 


\section{Conclusions}

The present work focuses on the micromorphological study of sands from some selected soil profiles developed in the surrounding area of the TDNP wetland. They are recent massive Arenosols (Calcisol in the transition area) developed over red paleosand layers. Despite their basic character, the carbonate content in the profiles was much lower than in the nearby soils, as well as their organic matter content. The analysis of the microstructures of the quartz grain surfaces displayed signatures of mechanical processes. Sub-angular to rounded grains, medium-to-low reliefs and smoothed edges were observed. Finally, numerous mechanical breakage features were detected including conchoidal fractures. These microstructures were more significant than signatures of chemical processes (precipitation of silica on the grain surface in lace-like patterns and corrosive etched microstructures that partially obliterated their surfaces), indicating their aeolian origin.

Most of the soil quartz grains in the profiles in this study were probably derived from soil or sediments from the surrounding area, transported by the wind, under more arid conditions. Their recent development indicates that the rubification process cannot take place in situ and that they are probably derived from degraded red soils.

\section{REFERENCES}

-Aguilera H, Moreno L, Jiménez-Hernández ME, Castano S, de la Losa A. 2011. Management implications inferred from the multivariate analysis of vadose zone chemical variables in Las Tablas de Daimiel National Park (Spain). Geoderma 162:365-377.

- Aleixandre T, Pinilla A, Pérez-González A. 1977. Caracterización mineralógica de las dunas continentales de la llanura manchega. In: Actas III Reunión Grupo de Trabajo del Cuaternario. Instituto de Geología Aplicada. p. 281-289.

- Álvarez-Cobelas M, Cirujano S, Sánchez-Carrillo S. 2001. Hydrological and botanical man-made changes in the Spanish wetland of Las Tablas de Daimiel. Biological Conservation 97:89-98.

- Álvarez-Cobelas M, Sánchez-Carrillo S, Cirujano S. 2007. Strong site effects dictate nutrient patterns in a Mediterranean floodplain. Wetlands 27:326-336.

- Bateman MD, Díez A. 1999. Thermoluminescence dates and palaeoenvironmental information of the late Quaternary sand deposits, Tierra de Pinares, Central Spain. Catena 34:277-291.

- Bateman MD, Godby SP. 2004. Late-Holocene inland dune activity in the UK: a case study from Breckland, East Anglia. The Holocene 14:579-588.

- Bernat M, Pérez-González A. 2005a. Procesos de erosión eólica en la llanura manchega. Tierra y Tecnología 28:47-56.

- Bernat M, Pérez-González A. 2005b. Campos de dunas y mantos eólicos de Tierra de Pinares (Sureste de la cuenca del Duero, España). Boletín Geológico y Minero 116(1):23-38.

- Bernat M, Pérez-González A, Rodríguez J, Bateman MD. 2011. Los sistemas eólicos del interior de España: Geomorfología eólica del Pleistoceno Superior y Holoceno de Tierra de Pinares y de la Llanura Manchega. In: San Jaume Saumell E, Gracia Prieto FJ, eds. Las dunas en España. Cádiz, Spain: Sociedad Española de Geomorfología. p. 13-85.

- Borja F, Pérez-González A. 2001. Formas y procesos eólicos. In: Gómez-Ortiz A, Pérez-González A, editors. Evolución reciente de la geomorfología española. Barcelona-Madrid, Spain: Ed. Rueda. p. 289-318.

- Cirujano S, Casado C, Bernués M, Camargo JA. 1996. Ecological study of Las Tablas de Daimiel National Park (Ciudad Real, Central Spain). Differences in water physico-chemistry and vegetation between 1974 and 1989. Biological Conservation 75-3:211-215. 
- Costa PJM, Andrade C, Mahaney WC, Marques da Silva F, Freire P, Freitas MC, Janardo C, Oliveira MA, Silva T, Lopes V. 2013. Aeolian microtextures in silica spheres induced in a wind tunnel experiment: Comparison with aeolian quartz. Geomorphology 180-18:20-129.

- Clemmensen LB, Pye K, Murray A, Heinemeier J. 2001. Sedimentology, stratigraphy and landscape evolution of a Holocene coastal dune system, Lodbjerg, NW Jutland, Denmark. Sedimentology 48:3-27.

- Conde-Bueno P, Martín-Rubí JA, Jiménez-Ballesta R. 2008. Environmental evaluation of elemental cesium and strontium contents and their isotopic activity concentrations in different soils of La Mancha (Central Spain). Environmental Geology 56:327-334.

- Crouvi O, Amit R, Enzel Y, Porat N, Sandler A. 2008. Sand dunes as a major proximal dust source for late Pleistocene loess in the Negev Desert, Israel. Quaternary Research 70:275-282.

- FAO. 2006. Guidelines for soil description. $4^{\text {th }}$ edition. Rome: FAO/UNESCO.

- Gee GW, Bauder JW. 1986. Particle-size analysis. In: Klute A, editor. Methods of soil analysis. Part 1. Physical and mineralogical methods. 2nd ed. Agronomy Monograph No.9. Madison, WI: ASA-SSSA. p. 383-411.

- Goran D. 2003. Terra Rossa in the Mediterranean region: parent materials, composition and origin. Geologia Croatica 56/1:83-100.

- Goudie A, Warren A, Jones D, Cooke R. 1987. The character and possible origins of the aeolian sediments of the Wahiba Sand Sea, Oman. The Geographical Journal 153:231-256.

- Goudie AS, Watson A. 1981. The shape of desert sand dune grains. Journal of Arid Environments 4:185-190.

- Helland PE, Holmes MA. 1997. Surface textural analysis of quartz sand grains from ODP Site 918 off the southeast coast of Greenland suggests glaciation of southern Greenland at $11 \mathrm{Ma}$. Palaeogeography, Palaeoclimatology, Palaeoecology 135:109-121.

- International Organization for Standardization. 1994. ISO 11265. Soil quality - Determination of the specific electrical conductivity. Geneva, Switzerland. 4 p.

- International Organization for Standardization. 1995. ISO 10693. Soil Quality - Determination of carbonate content - Volumetric method. Geneva, Switzerland. 7 p.

- IUSS Working Group WRB. 2006. World reference base for soil resources 2006. World Soil Resources Reports No. 103. Rome: FAO.

- Jiménez Ballesta R. 2010. Los suelos del entorno próximo de Las Tablas de Daimiel. In: Libro de Actas del IV Congreso Ibérico de Ciencia del Suelo. Granada, Spain. p. 1133-1145.
- Jiménez Ballesta R. 2014. Los suelos del Parque Natural de Las Tablas de Daimiel. Madrid: Ediciones UAM. 194 p.

- Kisch H. 1990. Recommendations on illite crystallinity. IGCP Project 294, VIGM 1-9.

- Kok JF, Parteli EJR, Michaels TI, Karam DB. 2012. The physics of wind-blown sand and dust. Reports on Progress in Physics 75:106901.

- Lancaster N. 1986. Grain-size characteristics of linear dunes in the southwestern Kalahari. Sediment Petrol. 56:395-400.

- Lancaster N. 1989. The Namib Sand Sea: Dune forms, processes, and sediments., Rotterdam, The Netherlands: A.A. Balkema. 200 p.

- Lisá L. 2004. Exoscopy of Moravian eolian sediments. Bulletin of Geosciences 79:177-182.

- Martín M, Jiménez-Ballesta R, Cala V, Álvarez A. 1992. Caracterización de la textura superficial de granos de cuarzo en suelos texturalmente contrastados. Suelo y Planta 2:259-270.

- Mitra S, Wassman R, Vlek P. 2005. An appraisal of global wetland area and its organic carbon stock. Current Science 88:25-35

- Moore DM, Reynolds RC Jr. 1989. X-ray diffraction and the identification and analysis of clay minerals. Oxford: Oxford University Press. $332 \mathrm{p}$.

- Moral-Cardona JP, Bellón AS, López Aguayo F, Caballero M. 1996. The analysis of quartz grain surfaces complementary method for studying their provenance: The Guadalete river basin (Cadiz, SW Spain). Sedimentary Geology 106:155-164.

- Muhs DR, Budahn JR, Reheis MC, Beann J, Skipp G, Fisher E. 2007. Airborne dust transport to the eastern Pacific Ocean off southern California: evidence from San Clemente Island. Journal of Geophysical Research 112: D13203. doi:10.1029/2006JD007577.

- Nelson DW, Sommers LE. 1982. Total carbon, organic carbon and organic matter. In: Page AL, Miller DH, Keeney DR, editors. Methods of Soil Analysis: Madison, WI: ASA-SSSA. p. 539-579.

- Pérez-González A, Cabra P. 1985. Mapa geomorfológico de España escala 1:50.000. Hoja de la Roda (742). Madrid: ITGE.

- Pérez-González A, Piles P. 1985. Mapa geomorfológico de España escala 1:50.000. Hoja de Villarta de S. Juan (738). Madrid: ITGE.

- Peter K, Tietz G. 2011. Chattermark trails: surface features on detrital quartz grains indicative of a tropical climate. Journal of Sedimentary Research 81:153-158. 
- Portero JM, Ramírez JI. 1985. Mapa geomorfológico de España escala 1:50.000. Hoja de Daimiel (760). Madrid: ITGE.

- Pye K, Mazzullo J. 1994. Effects of tropical weathering on quartz grain shape: an example from Northeastern Australia. Journal of Sedimentary Research 64:500-507.

- Ravi S, Breshears DD, Huxman TE, D'Odorico P. 2010. Land degradation in drylands: Interactions among hydrologic-aeolian erosion and vegetation dynamics. Geomorphology 116:236-245.

- Rendell HM, Calderón T, Pérez-González A, Gallardo J, Millán A, Townsend PD. 1994. Thermoluminiscence and optical simulated luminiscence dating of Spanish dunes. Quaternary Geochronology (Quaternary Science Reviews) 13:429-432.

- Ries JB, Marzen M, Iserloh T, Fister W. 2014. Soil erosion in Mediterranean landscapes - Experimental investigation on crusted surfaces by means of the Portable Wind and Rainfall Simulator. Journal of Arid Environments 100-101:42-51.

- Rodríguez García JA. 1998. Geomorfología de las Tablas de Daimiel y del endorreísmo Manchego CentroOccidental. Bachelor Thesis. Madrid: Complutense University of Madrid. $164 \mathrm{p}$.

- Rodríguez JA, Pérez-González A. 2002. Geomorfología de las Tablas de Daimiel y su entorno. In: Pérez-González A, Vegas J, Machado MJ, editors. Aportaciones a la geomorfología de España en el inicio del tercer milenio. p. $465-473$.

- Rodríguez-Murillo JC, Almendros G, Knicker H. 2011. Wetland soil organic matter composition in a Mediterranean semiarid wetland (Las Tablas de Daimiel, Central Spain). Insight into different carbon sequestration pathways. Organic Geochemistry 42:762-773.

- Roskin J, Blumberg DG, Porat N, Tsoar H, Rozenstein O. 2012. Do dune sands redden with age? The case of the northwestern Negev dunefield, Israel. Aeolian Research 5:63-75.

- Ruiz Zapata MB, Pérez-González A, Dorado Valiño M, Valdeolmillos Rodríguez A, Gil García MJ. 2000. Caracterización de las etapas áridas del Pleistoceno Superior en la región Central penínsular. Geotemas 1(4):273-278.

- Sánchez-Carrillo S. 2000. Hidrología y sedimentación actual de Las Tablas de Daimiel. Dissertation. Madrid: Universidad Autónoma de Madrid.

- Sánchez-Carrillo S, Álvarez-Cobelas M, Angeler DG. 2001. Sedimentation in the semi-arid freshwater wetland Las Tablas de Daimiel (Spain). Wetlands 21:112-124.
-Sánchez-Carrillo S, Angeler DG, editors. 2010. Ecology of Threatened Semi-Arid Wetlands: Long-Term Research in Las Tablas de Daimiel. Series Wetlands: Ecology, Conservation and Management. 2. Springer-Verlag Gmbh. 293 p.

- Sierra M, Martínez FJ, Sierra C, Aguilar J. 2009. Correlations between pedological parameters in relation to lithology and soil type in Almeria (SE Spain). Journal of Arid Environments 73:493-498.

- Soil Survey Staff. 2006. Keys to Soil Taxonomy. $10^{\text {th }}$ edition. USDA-NCRS.

- Sun D, Bloemendal J, Rea DK, Vandenberghe J, Lu H, Su R, Liu T. 2004. Bimodal grain-size distribution of Chinese loess, and its palaeoclimatic implications. Catena 55:325-340.

- Torcal L, Tello B. 1992. Análisis de sedimentos con microscopio electrónico de barrido: exoscopía del cuarzo y sus aplicaciones a la Geomorfología. Cuadernos Técnicos de la Sociedad Española de Geomorfología No 4. Logroño, Spain: Geoforma Ediciones. 32 p.

- Trinidade MJ, Prudêncio MI, Sánchez JS, Romaní JRV, Ferraz T, Mosquera DF, Dias MI. 2013. Post-depositional processes of elemental enrichment inside dark nodular masses of an ancient aeolian dune from A Coruña, Northwest Spain. Geologica Acta 11:231-244.

- Vos K, Vandenberghe N, Elsen J. 2014. Surface textural analysis of quartz grains by scanning electron microscopy (SEM). From sample preparation to environmental interpretation. Earth Science Reviews 128:93-104.

- Wasel SO. 2012. Microtextures of quartz grain surface from recent sedimentary environments along Alkhowkhah-Al-mokha coastal area, southern Red Sea, Yemen. Journal of King Abdulaziz University, Marine Science 23:93-107. 